\title{
A Forgotten Philosopher Juozapas Čepėnas: Ethic Insights
}

\author{
LIUDMILA MOCKIENE், LORA TAMOŠIŪNIENĖ, RŪTA MARIJA VABALAITE் \\ Institute of Humanities, Mykolas Romeris University, 20 Ateities Street, 08303 Vilnius, Lithuania \\ Email: liudmila@mruni.eu; lora@mruni.eu; marijavabalaite@mruni.eu
}

\begin{abstract}
The article deals with ethic insights of the priest Juozapas Čepenas (1880-1976), who published a study cycle on Nietzsche. This cycle is significant in the context of an early reception of Nietzsche's ideas in Lithuania; however, the author himself appears to remain an undeservedly forgotten thinker of the national school of thought. The article attempts to bring back Čepenas' philosophical outlooks and analyse the factors that shaped his philosophical position such as his academic upbringing in German classical universities and Čepenas' subsequent activities overstepping the boundaries of a clerical work. The article offers a new interdisciplinary approach in reviewing Čepenas' dissertation thesis that earned him a Degree of Doctor of Philosophy of Freiburg University. The thesis is analysed in comparison to other Čepenas' philosophical writings on Dostoevsky produced at the period of university studies and later during his clerical service in Lithuania. Ethical aspects of Čepenas' thesis continue to hold relevance until the recent period of philosophical development. Čepenas' writings are viewed in parallel analysis with a spectrum of the Lithuanian existential thought. Critical contemplations on ethical principles in the cycle of articles on Nietzsche's philosophy are emphasised. The article attempts to clarify Čepenas' understanding of the egotism of the superhuman, the reasons and the content of supplements of Christian ethics, and the concept of the secular purpose of life.
\end{abstract}

Keywords: Dostoevsky, Nietzsche, existential problems, worldview, genealogy of morals

\section{INTRODUCTION}

The philosophical works of the priest Juozapas Čepenas (1880-1976) are practically unknown even in Lithuania, his home country. In recent decades, historians of the Catholic Church of Lithuania have published scientific works on Juozapas Čepènas' activity (Vasiliauskienè 2001), the autobiography written by the author himself (Čepenas 2010) and a book compiled by his nephew (Čepenas 2012), which includes the author's dissertation and a study of mass psychology. However, Čepènas' philosophical legacy has not attracted so far due attention of the historians of Lithuanian philosophy. This article discusses the main philosophical ideas of Čepenas' works since, in view of the authors of this article, Čepènas deserves to be listed among the founding philosophers of Lithuanian philosophical thought, and the status of 'a forgotten writer' may have been sealed historically due to ideological reasons. This article seeks to restore the unbiased approach to the writings of Čepenas. 
Čepenas in his dissertation and in his random articles paid a fair share of his attention to the moral ideas of Dostoevsky and Nietzsche. Čepenas was profusely interpreting Nietzsche, the fact that singles him out of the context of the Lithuanian philosophical discourse of the day. This situation naturally leads to a question of the influences that Čepenas must have experienced and calls for a review of the evidence from his biography that proves his research interests and academic experience to remain unbound by theological frames. Parts 2 and 3 of this article focus on the ethical aspects of Čepenas' writings on philosophical positions of Dostoevsky and Nietzsche. Recent publications on these positions show that the historical perspective of moral philosophy is meaningful in the analysis of modern ethical controversies (Stewart 2016; Snelson 2017; Beary 2018). Famous former interpretations of good and evil supported by non-theological arguments, and the attempts to provide secular interpretation of the human essence are still under many discussions (Nemchynov 2013; Auweele 2016; Leiter 2019; Holub 2019, van Fossen 2019). Therefore, a more attentive approach to the interpretations of texts written by the philosophers, participants of such discussions, is of deep significance and of an unending attention. On balance, the scrutiny of Čepenas' ideas might propose a case study for present day philosophy historians, who are interested in the spread of German philosophical ideas among the students of Eastern Europe.

\section{FACTORS THAT FORMED ČEPĖNAS' PHILOSOPHICAL VIEWS AND HIS SECULAR ACTIVITIES}

In the article 'The Reception of Philosophy of Friedrich Nietzsche in Lithuania Before World War II' (Vabalaite 2013: 9), it was stated that the positions of a Catholic theology proponent did not prevent Čepenas from impartial and profound evaluation of the positive moments in Nietzsche's worldview. This circumstance has facilitated further advance into the analysis of formation of Čepenas' philosophical interests and their expressions. The chronology of the author's life and activities indicates that a priest-to-be studied at Vilnius Gymnasium in 1892-1900, later at the Samogitian Seminary in 1901-1905 (Vasiliauskiene 2001: 126). His own memories reveal that at that time he already dared to think independently, and even though he was a brilliant student, he had his reservations about his future successful career as a priest. Pranas Čepėnas, a well-known historian, emigrant and Juozapas Čepėnas' own brother, describes instances when Juozapas Čepėnas because of his obstinate adherence to his own principles and his disobedience repeatedly suffered from secular authorities and sometimes also experienced disfavour of ecclesiastical superiors (Čepènas 1970: 466). Nevertheless, in 1919 Čepenas was granted permission from the Catholic Church to continue studies in Germany. In his memoirs, Čepėnas admits that while his friends encouraged him to opt for theology, he chose to study philosophy at the University of Freiburg. While studying in Freiburg, he sought to listen to as many different professors' lectures as he could and in the middle of his studies, he relocated to the University of Munich for three semesters. The most remarkable excerpt from the memoirs from the point of view of the history of philosophy can be cited:

'At that time there were famous professors at the Faculty of Philosophy, e.g.: Edmund Husserl, the phenomenologist. His lectures were attended by the English and the Americans and he was invited to lecture during the holidays. Prof. Joseph Geyser had many listeners and many students had promotions under his guidance because Husserl accepted dissertations from the area of phenomenology only. Prof. Geyser wrote many different works, as well as prof. Cohn, prof. Kroner Hegelian and many other good professors whose lectures were a pleasure to listen to because they provided interesting material. During the first three semesters, I listened to at least six lectures every day' (Čepènas 2010: 119). 
Unfortunately, this is the only place where the future doctor of philosophy mentions Husserl, so it is impossible to establish whether Čepenas did not become particularly interested in phenomenology himself or whether his study choice was determined by other reasons. Nearly a century later, it can only be referred to the biography guide ${ }^{1}$ in order to find out why he mentioned the above professors and why they posed interest to him. Among all professors at the University of Freiburg, Čepenas distinguishes Arthur Allgeier and Joseph Geyser as the ones with whom he later corresponded (Čepenas 2010: 118). By the way, Geyser was the scientific supervisor of his dissertation 'Psychologische Analyse der Persönlichkeit und der Werke Dostojewskis' (A Psychological Analysis of Fiodor Dostoevsky’s Personality and his Works) successfully defended in 1924.

After returning to Lithuania, already a Doctor of Philosophy, he resumed his church duties and, time permitting, studied the works of German, English and French philosophers (Čepenas 2012a: 24), he found more pleasure in books and educational work than in pastor's functions (Čepenas 2012a: 21), he took care in preservation of the standard Lithuanian language, and convened several cultural associations. In his memoirs, Čepenas admits that he was very fond of being the director of Zarasai Gymnasium and a lecturer of a two-year course for teachers (Čepėnas 2010: 121) when he taught future teachers pedagogy, logic and psychology and volunteered educational activities for the local community. Historical sources reveal that Čepenas collaborated in the cultural press and was a member of the Lithuanian Society of Science. During the war, the priest tried to rescue the Jews, and in the postwar period, he fell victim of Stalinist repressions (Čepėnas 1970: 465). The manuscript of his major work 'The Man' was confiscated during police search and was never rediscovered since. The reconstruction of the philosophical views of the philosopher-priest can be delivered only from the remaining texts: the aforementioned dissertation thesis (Čepenas 2012b: 48-119), articles written under a penname on Nietzsche in the journal Culture (Agaras 1925; Agaras 1926) and a study on the mass psychology written in the late sixties of the 20th century (Čepènas 2012c: 120-152). ${ }^{2}$

\section{THE ANALYSIS OF ETHICAL PROBLEMS IN ČEPĖNAS' DISSERTATION}

Jonas Minkevičius, an eminent professor of architecture, indicates that his supervisor Juozapas Čepennas wrote and defended a dissertation 'A Psychological Analysis of Fiodor Dostoevsky's Personality and his Works' that preserves its relevance to our present period both from the scientific and moral points of view (Minkevičius 2012: 47) and that the presented analysis has not been paralleled so far either in the Western scholarship, or in Lithuania. Thus the thesis must be considered a novel word in the field of studies, and it remains novel internationally (Minkevičius 2012: 45). The question is if this laudation springs more from Minkevičius' gratitude to his supervisor, or from more objective incentives.

We must admit that Čepenas was neither the first nor the only Lithuanian philosopher interested in moral problems raised in Dostoevsky's works. According to the scholars among

1 Based on the data of 'Neue Deutsche Biographie' issued since 1953 (Vol. 1: 202; Vol. 3: 316, Vol. 6: 363364, Vol. 13: 84-86), Arthur Allgeier (1882-1952) was a researcher who analysed the Old Testament, John Cohn (1869-1947) was an advocate of neo-Kantian Baden school, Josef Geyser (1869-1948) was a philosopher of critical realism, Richard Kroner (1884-1974) was a neo-Hegelian, a researcher of the history of German philosophy (it is him who Čepenas remembers as a 'Hegelian').

2 The research of this work would go beyond the subject of the article, so it is necessary to postpone it for later study. 
the early researchers of Dostoevsky was Vydūnas, who commemorated the hundredth anniversary of the creator in a short article in the journal Darbymetis (Busy Season) which he published himself (Varlašina 2009: 4-5). The bibliography list of Čepènas' dissertation includes two Lithuanian texts. The first is the study of the thoughts inspired by Dostoevsky's daughter on the Lithuanian roots of the writer (Gustainis 1921: 2), the other text is a review of Dostoevsky's outlooks but not an assessment of these ideas a priori deemed by Čepenas' religious beliefs, but a study of the importance of Dostoevsky's works for the readers through their connection to his Lithuanian ancestry (Gucaitis 1922: 26-42). ${ }^{3}$

Čepenas justified his choice of the doctoral dissertation theme not claiming any special philosophical insights. He indicated that his supervisor, who knew that the activity of German researchers was limited by their inability to read texts published in the Russian language, advised him to provide easier understanding of Dostoevsky's ideas for those who do not understand Russian. In his dissertation, Čepénas refers to the works of Dostoevsky's contemporaries published in Russian, on the book by Freud's student Jolan Neufeld, on works of German publicists. Throughout the whole of thesis Čepenas does not refer to many philosophical postulates; however, in a few places he draws a comparison of Dostoevsky's ideas to moral theories of Kant and Nietzsche. In the opening part of his dissertation Čepenas included a quote from Nietzsche that Dostoevsky is 'the only psychologist from whom I learned something: Dostoevsky was linked to the happiest coincidences in my life, even more than the discovery of Stendhal (Nyčès kūryba, VIII, 158. Leipcigas, Kroner 1912)' (Čepenas 2012b: 48). The dissertation several times compares Dostoevsky's and Nietzsche's views on crime, on the development of human morality and Christianity and arrives at the conclusion that they both were atheists to a certain degree (Čepenas 2012b: 85); however, unlike Nietzsche, Dostoevsky wanted to keep his faith, since he was able to see some negative impact of atheism on moral attitudes. Čepenas sees that Dostoevsky considered the question of God's existence from the position of the Kantian philosophy, recognizing that pure speculative reason could not perceive nor prove God's existence and left such issues to practical reason.

Čepenas, then the prospective Doctor of Philosophy, measured Christian issues against the background of other philosophers accepting limits of metaphysics and did not seek for dogmatic solutions. In this respect he stands out favourably from many local interpreters of Dostoevsky's works, even from those whose works are more advanced in time than his. It is a well-known fact that an eminent Lithuanian philosopher Antanas Maceina in 1946 published a study in which he commented on the myth of the Grand Inquisitor in Dostoevsky's novel 'The Brothers Karamazov'. These comments, however, show that Maceina must not have been searching deep for the answers to the fundamental Christian quests, as he relied on the supreme answers and stated them. A similar verdict can be passed on an article by a less known philosopher Valdemaras Cukuras 'Dostoevsky and Our Times' ('Dostojevskis

3 In the article published in the journal Draugija (Brotherhood) (Gucaitis 1922: 26-42) the analysis of Dostoevsky's ideas is based on Valentinas Gustainis' statement about the Lithuania roots of the profound novelist (Gustainis 1921: 2), rather than based on their value per se. The text introduces the writer's biography and describes topicality of his novels, distinguishes Dostoevsky's ability to identify the heroes' experiences with one's own, and the need of each small person to be recognized as a central theme for his value to be acknowledged. He raises the question about the relationship of the heroes and the author himself with the Christian faith and does not seek to create the impression that the faith was Dostoevsky's 'answer' to the distressing issues of existence. 
ir mūsu laikai'), in the magazine Aidai in 1949, where Dostoevsky is proclaimed 'a father and a founder' of a deepened Christian humanism (Cukuras 1949: 187). ${ }^{4}$

In Čepènas' dissertation, Dostoevsky's intellectual lifeline is analysed with the emphasis on the political confrontations in Russia of that period and their effect upon the convictions of the great novelist as well as with an individually treated meaningful moments in the writer's life, their psychoanalytical aspects, circumstances, experiences, and endurance. The most significant is Čepenas' conclusion of the complexity of Dostoevsky's inner existence and interior coexistence of irrevocable contradicting convictions about the unity of the universe and the place of the individual in that space revealed in his novels. This conclusion makes it possible for Čepènas to identify the diversity of Dostoevsky's characters' world outlooks that resist reduction to a single truth, to use a term of Michail Bachtin, a certain heteroglossia of characters. This gives a chance to approach each separate character as an exceptional focal point of the world and of oneself being the basic meaningful position for valuation of oneself and the surrounding reality (Bachtin 1996: 57). ${ }^{5}$

Čepenas' reading of Dostoevsky's novels, essays and diaries is not exceptional in its own right, it stands in compliance with one of the break of 20th-century literary analysis methods that held its imperative 'to look into moral, social, philosophical, religious images and concepts that feed the soil of the author's intellectual life' (Lansonas 1989: 152). On the other hand, a deep involvement with the issues raised by Dostoevsky enabled Čepenas to identify and to analyse the moral dilemmas of equally significant importance to the individuals nowadays in far wider contexts than Russian megacities. They all grow out of the clash of indifferent powers active in the surrounding world and the meaning of their impact is beyond the individual capacity to understand, justify or change them. Čepėnas studies of multitiered and controversial social reality encourage individuals who cannot find their orientation to seek limits of self-actualisation need. Self-actualisation in some individuals grows into egotism and vulnerability of others makes them accept reduced human needs. Foreshadowing the appearance of the concept of thrownness Čepenas diagnoses the condition of Dostoevsky's human being as 'influenced by chances, affected by unplanned accidents and impulses' (Čepénas 2012b: 119) and the soul of such individual contains no simple item, all is in the 'conglomerate of feelings, in a transient shape' (Čepenas 2012b: 119). The scope of existential problems can be foreseen in defining human existence by Dostoevsky when Čepènas states in paraphrases of one of Dostoevsky's characters that the writer constructs 'an ideal in being who you are not; in sensing what you cannot sense; in thinking as you are not used to think; in living as you do not live. For this reason, he wants to believe since he does not, he wants to succumb since he is proud' (Čepenas 2012b: 81).

Čepenas approaches the effect of social status upon human self-esteem and ethic convictions from the position of philosophical anthropology. He produces a typology of characters' self-esteem which is put on the platform of self-belief within the context of world order. In this way Čepenas introduces a typology that later became known as 'a structure of internal orientations of culture actors towards their experiences' (Kavolis 1994: 125). Čepenas is approaching the full spectrum of 'consciousnesses', from a minimal emotional contact with

4 Dostoevsky's ideas were analysed in more detail by Cukuras in his doctoral dissertation defended at Pontifical Gregorian University in Rome in 1948 - 'On Religious Anxiety in Dostoevsky's Works'.

5 Bachtin analysed Dostoevsky's works in a similar period - in 1920-1924 - as well as Čepenas, both of them relied on the most prominent sources of that time, thus it is not surprising that the author we are analysing came to acknowledge non-monologue prose. 
the environment determined by an utmost deprivation of economic welfare, to differential intellectual worldviews of the characters: one of ideologised philosophy, another of religious metaphysics, and, yet, another of 'egotist-metaphysics' (Čepenas 2012b: 108) all of which take shape in the eye of emerging global catastrophes in hope of restoring justice. The key variations of the worldviews and practical standpoints in the philosopher's opinion are dualistic, egoistic and altruistic in character while neither seems to be an optimal position.

Dualists are known by their desires for what they cannot attain, by their striving to probe into their personal sense of honour and by their denigrating daily struggle to survive, by selfwill, pride and sorrow. Some of them, the most intelligent ones, immerse in self-analysis and reflection of social and moral relations, they are unable to settle the parity between flesh and soul, mind and will.

The salient feature of egotists is 'a fusion of complete primitive mind and primitive will' (Čepenas 2012b: 101), they protest against society and universal order, they put their faith into a spirited liberated individual, who builds a world and alters it to suit his will.

Altruists resort to 'the same source as egotists, which are hardships of life and sufferings, pressing poverty, social and economic decline' (Čepenas 2012b: 109), but the response of the great majority to the hardships is a total loss of hope, submissiveness, self-depreciation. They hold on their faith and hope though some of them promote the idea of contemplating a harmonious society.

Among altruists there is an agent who is submissive not because it is determined so by the circumstances, but because of the internal need. While studying the religious metaphysics of an austere altruist, Čepenas defines it in thoughts revealing the existential philosophical approach: 'since cosmos is and will remain unreasonable mystery for the mind, the heart, feelings and faith [human wish] is to see an endless harmony behind a contrast and to hear a remarkable rhythmic sound of universal metamorphosis' (Čepenas 2012b: 115). Čepénas in great detail and with a positive attitude brings out the religious worldview constructed by this agent and on the basis of such worldview emerging the social and ethnic ideal, but he indicates the flaws of this position as well. To quote his words, 'Dostoevsky did not wish for one-sided surrender, silence and destruction that lead to Buddhist nirvana. He, however, was equally frightened by a rigorous egotism. He is fond of his altruists but he rejects passiveness' (Čepenas 2012b: 117). This makes it possible to assume that Čepenas, the author of the dissertation, exercises a critical review of the ethic positions of all characters and accepts everyone's vulnerability in the manner Dostoevsky does himself.

\section{THE ANALYSIS OF ETHICAL PROBLEMS IN ČEPĖNAS' ARTICLES}

Čepenas continues contemplating premises for a harmonious coexistence of individuals in the journal Kultüra in the published cycle of articles on Nietzsche. The author invites all to search for the positive ideas of the genealogy of morals, to fathom why Nietzsche critically approached teachings of Christian ethics, which features he missed in the modern humanity and what was his vision of superbeings rising above humanity. Čepenas insists that Nietzsche did not seek to discredit the principles of Christian behaviour but to give them a critical review and assessment.

Čepenas in writing about the Nietzschean concept of the morality of slaves indicates that 'the good today is proclaimed what suits the mass, the crowd, - the evil is what is not attainable for the crowd, and causes fear for one's neighbour' (Agaras 1925: 521). Čepenas writes that in accepting such mutating reality one should accept the fact that 'eternal' truths 
and norms cannot remain unchanged. One who complies with the existing order of things is not privileged a priori in comparison to the one who is building new theories and ideals. Čepenas treats the Übermensch not in 'a body, but soul perspective' (Agaras 1925: 247), as well as Nietzschean power is not merely a physical power because 'the more power there is the more mind is present and the more mind is present the more power there is' (Agaras 1926: 23). Life is full of hardships and sufferings, but we should not despair or expect a reward in posthumous life. The aim of existence could be the improvement of a human being and 'we should not wish for the effort we put into it any personal profit or income' (Agaras 1926: 249). Though we cannot define the ideal of humanity, its advancement is implied in the theory of evolution of life. Čepenas stresses that 'Nietzsche worships egotism, which upgrades the life of all humanity, but he hates egotists - the exploiters of societies' (Agaras 1926: 307). The most powerful are those, who spread their powers and 'collect into their souls all possible riches' (Agaras 1926: 306) for the sake of advancement of human beings, but not for the sake of fame so deeply rooted in the modern society today, nor for the sake of profit.

The fact should be acknowledged that Čepenas does not indicate in a positive manner any milestones for the future creativity, he chooses to remind that after a prolonged admiration of minor individuals there could arise a longing for grand individuals. Čepènas considers Nietzsche's main virtue in his call to approach critically all convictions or behavioural principles.

\section{CONCLUSIONS}

Today it is difficult to identify if Čepenas' interests in philosophy determined his choice of doctoral studies in Freiburg University or all happened in a reverse manner, i.e. the studies influenced his philosophical views. This question remains unanswered since the application of the biography analysis method is limited through a small number of remaining sources and the application of a comparative-historic method to verify the alteration of Čepenas' philosophical views is invalid since Čepenas did not publish any philosophical essays before his studies in Germany. However, the historical comparison to other philosophical ideas made public by his fellow philosophers in Lithuania allow us to conclude that Čepènas distinguishes himself from many other philosophers in Lithuania at that time by his endeavours to study problems of moral relations of an individual and the individual's environment without any prior ideological engagement. In search for a possibility to achieve harmony between an ordinary human being and society Čepėnas addresses a non-monological but a polyphonic idea of Dostoevsky's novels. To a certain extent, Čepenas' open philosophical views upon an ordinary urban dweller's need to comprehend world harmony and one's attempts to find or make a place for oneself in it, and Čepènas' reflections on human limits, thrownness and pointless sufferings can aspire to the initiation of Lithuanian existential thinking. In his interpretation of the Nietzschean genealogy of morals and the concept of Übermensch a search for a more fair life could be discerned which is a contrast to the dominant Thomistic context of a philosophical thought in Lithuania at the time of Čepenas' writings. Nietzsche in this approach is shown as the one who sees the flaws in modern ethic principles and in search of more advanced principles with a secular grounding. In both his works, Čepenas reveals himself as a philosophical analyst who multi-sidedly reflects ethical problems and refrains from easy conclusions in his search. 


\section{References}

1. Agaras, J. 1925. „Fridrikas Nicšě“, Kultūra 10: 468-473; 11: 519-523; 12: 583-586.

2. Agaras, J. 1926. „Fridrikas Nicšè“, Kultūra 1: 20-24; 4: 190-194; 5-6: 246-251; 7-8: 305-308.

3. Auweele, D. 2016. 'Existential Struggles in Dostoevsky's the Brothers Karamazow, International Journal for Philosophy of Religion 80(3): 279-296.

4. Bachtin, M. 1996. Dostojevskio poetikos problemos. Vilnius: Baltos lankos.

5. Beary, A. 2018. 'The Curious Case of Ivan Karamazov: A Thomistic Account of Wisdom and Pride', Heythrop Journal 59(1): 34-44.

6. Cukuras, V. 1949. „Dostojevskis ir mūsų laikai“, Aidai 25: 187-188.

7. Čepėnas, J. 2010. Sacerdos in aeternum. Velaikiu Juozelio atsiminimai. Kaunas: Lututè.

8. Čepenas, J. 2012a. „Filosofijos daktaro kunigo Juozapo Čepeno gyvenimo ir veiklos apžvalga“, iš Velaikiu Čepènai: giminès istorija, sud. J. Čepènas. Vilnius: Petro ofsetas.

9. Čepènas, J. 2012b. „Dostojevskio asmenybès ir kūrybos psichologinè analizë“, iš Velaikiu Čepènai: giminés istorija, sud. J. Čepènas. Vilnius: Petro ofsetas, 48-119.

10. Čepènas, J. 2012c. „Masių psichologija“, iš Velaikiu Čepènai: giminès istorija, sud. J. Čepėnas. Vilnius: Petro ofsetas, $120-152$.

11. Čepènas, P. 1970. Kun. dr. J. Čepènas, Aidai 10: 464-466.

12. van Fossen, J. A. 2019. 'Nietzsche, Self-Disgust, and Disgusting Morality', Journal of Nietzsche Studies 50(1): 79-105.

13. Gucaitis, P. 1922. „T. Dostojevskis“, Draugija 1-2(131-132): 26-42.

14. Gustainis, V. 1921. „Ką Dostojevskio duktè rašo apie lietuvius?“, Laisvè 272: 2.

15. Holub, G. 2019. 'Human Dignity: Between the Existentialist and the Essentialist Approaches', Filosofija. Sociologija 30(3): 206-214.

16. Kavolis, V. 1994. Žmogus istorijoje. Vilnius: Vaga.

17. Lansonas, G. 1989. „Literatūros istorija“, iš Poetika ir literatūros estetika, sud. V. Zaborskaitè. Vilnius: Vaga, 140-165.

18. Leiter, B. 2019. 'Death of God and the Death of Morality', Monist 102(3): 386-402.

19. Minkevičius, J. 2012. „Pratarmè kun. J. Čepėno traktatui „Dostojevskio asmenybès ir kūrybos psichologinè analizè “', iš Velaikiu Čepènai: giminès istorija, sud. J. Čepènas. Vilnius: Petro ofsetas, 45-47.

20. Nemchynov, I. 2013. 'The Antinomies of the Freedom, or the Three Temptations of Dostoevsky', Sententiae 29(2): 37-46.

21. Snelson, A. 2017. 'The History, Origin, and Meaning of Nietzsche's Slave Revolt in Morality', Inquiry 60(1/2): $1-30$.

22. Stewart, J. 2016. 'Dostoevsky and the Novel as Philosophy', Working Papers in Philosophy: Registers of Philosophy 4: 1-17.

23. Vabalaite, R. M. 2013. „Friedricho Nietzsche’s filosofijos recepcija ikikarinëje Lietuvoje“, Logos 75: 6-12.

24. Varlašina, M. 2009. „Teigiamo santykio su Dostojevskio kūryba problema: Vydūnas“, Literatūra 51(2): 4-18.

25. Vasiliauskienè, A. (sud.) 2001. Filosofijos daktaras kunigas Juozapas Čepènas. Vilnius: Regnum fondas. 
LIUDMILA MOCKIENE், LORA TAMOŠIŪNIENE், RŪTA MARIJA VABALAITÉ

\title{
Etinès užmirštojo filosofo Juozapo Čepèno idẻjos
}

\begin{abstract}
Santrauka
Analizuoti kunigo Juozapo Čepėno (1880-1976) moralès filosofijos idejjas skatina tai, kad nors jis ir yra publikavęs straipsnių apie F. Nietzschęę ciklą, bet kaip filosofas nèra gerai žinomas. Pirmiausia straipsnyje aptariami J. Čepèno filosofines pažiūras suformavę veiksniai, jo studijos Vokietijos universitetuose ir vélesnè dvasininko pareigas peržengianti veikla. Dèl tarpdisciplininio bendradarbiavimo atsiradus galimybei ịsigilinti ị kunigo disertaciją apie F. Dostojevskị, už kurią jam buvo suteiktas Freiburgo universiteto filosofijos daktaro laipsnis, straipsnyje publikuojama šio nepelnytai primiršto mąstytojo etinių idèjų analizè. Disertacija lyginama su tų laikų ir vèlesnèmis lietuvių filosofų nuostatomis apie F. Dostojevskio kūrybą, išskiriami aktualumo nepraradę jos etiniai aspektai, išryškinama jos reikšmė egzistencinès lietuvių filosofijos krypties idejjų diskurse. Analizuojami ciklo apie F. Nietzsche’s filosofiją kritiški etinių principų apmąstymai. Atkreipiamas demesys ị pastangas paaiškinti, ką reiškia stipriųjų egoizmas, kodèl ir kuo verta papildyti krikščioniškają etiką, kokia gali būti pasaulietiška gyvenimo tikslo samprata.
\end{abstract}

Raktažodžiai: Dostojevskis, Nietzsche, egzistencinès problemos, pasaulěžiūra, moralès genealogija 